\title{
INTRODUCTION TO SYMPOSIUM ON THE MANY LIVES AND LEGACIES OF SYKES-PICOT
}

\author{
Antony T. Anghie*
}

Although their motivations varied, many senior British officials who were expert in imperial and MiddleEastern matters condemned the Sykes-Picot treaty as a mistake almost as soon as it was signed. ${ }^{1}$ T.E. Lawrence wanted the British government to repudiate it and was assured by Gilbert Clayton, the head of the Arab Bureau in Cairo, in a letter he wrote to Lawrence in 1917, that "It is in fact dead and, if we wait quietly, this fact will soon be realized'."2 Lord Curzon denounced the treaty as "not only obsolete "but absolutely impracticable,"3 and further declared that only "gross ignorance" could account for the boundary lines in the treaty. ${ }^{4}$ Sir Mark Sykes was said to be ashamed of his involvement in the Treaty that was to bear his name ${ }^{5}$. Despite these efforts, so soon after its birth, to announce the demise and irrelevance of Sykes-Picot, its complex, variegated, and evolving legacy has survived and is still very much with us.

Ever since it was made public by the Bolsheviks in 1917, the treaty negotiated by Sir Mark Sykes on behalf of the United Kingdom and Francois George-Picot on behalf of France has been a source of immense controversy which has only escalated over time. Sykes-Picot is seen as an embodiment of imperial interference in the Middle East and a major cause of the ongoing violence and instability that has afflicted the region. The centenary of Sykes-Picot in May 2016 generated responses, from scholars and Middle East specialists, as well as Daesh which dramatically bulldozed part of the border between Syria and Iraq in a symbolic effort to bury Sykes-Picot once and for all.

The treaty itself divides up large swathes of the Middle East into French and British spheres of influence (the French sphere is marked 'A' and the British sphere is marked 'B' in the accompanying map which was attached to the Treaty) - a common enough practice among rival imperial powers of the nineteenth and early twentieth centuries. It contemplates the existence of an Arab state or a Confederation of Arab states within those spheres of influence, and indeed, undertakes to recognize and uphold such entities. Within their respective spheres, the United Kingdom and France "shall be allowed to establish such direct or indirect

* Professor of Law, National University of Singapore.

We are grateful to John Louth and Oxford University Press which has granted us permission to link this Symposium to materials on the Sykes-Picot Treaty made available on the superb OUP blog.

Originally published online 28 September 2016.

${ }^{1}$ For further information on the Sykes-Picot agreement, see The Sykes-Picot Agreement May 1916, Oxford Public InTERNATIONAL LAW, and Umut Özsu, Sykes-Picot: the treaty that carved up the Middle East, OUPBLOG (May 9, 2016).

2 Cited in David Fromkin, A Peace to End All Peace: the Fall of the Ottoman Empire and the Creation of the Modern MidDLE EAST 342-43 (1989).

${ }^{3} \underline{I d}$. at 343 .

${ }^{4} \underline{I d}$. at 344

${ }^{5} \underline{I d}$. at 344 
administration or control as they desire and as they may think fit to arrange with the Arab State or Confederation of Arab States." Significantly, Article 11 of the Agreement contemplates "negotiations with the Arabs as to the boundaries of the Arab State or Confederation of Arab States," a mechanism which was never used in the final settlement of the boundaries of the relevant states. ${ }^{6}$ Much of Sykes-Picot is devoted to commercial and trade arrangements, to access to ports and the construction of railways. Thus, for instance, Alexandretta was designated a "free port" with regard to British Empire trade, and reciprocally, Haifa was a free port for goods from the French Empire. This preoccupation with trade and commerce is also characteristic of interimperial arrangements. The Treaty of Berlin of 1885, equated notoriously with the imperial carving up of Africa, is prominently a free trade agreement which also deals with navigational rights. Questions of governance and sovereignty, then, were inextricably linked in such agreements with trade and commerce.

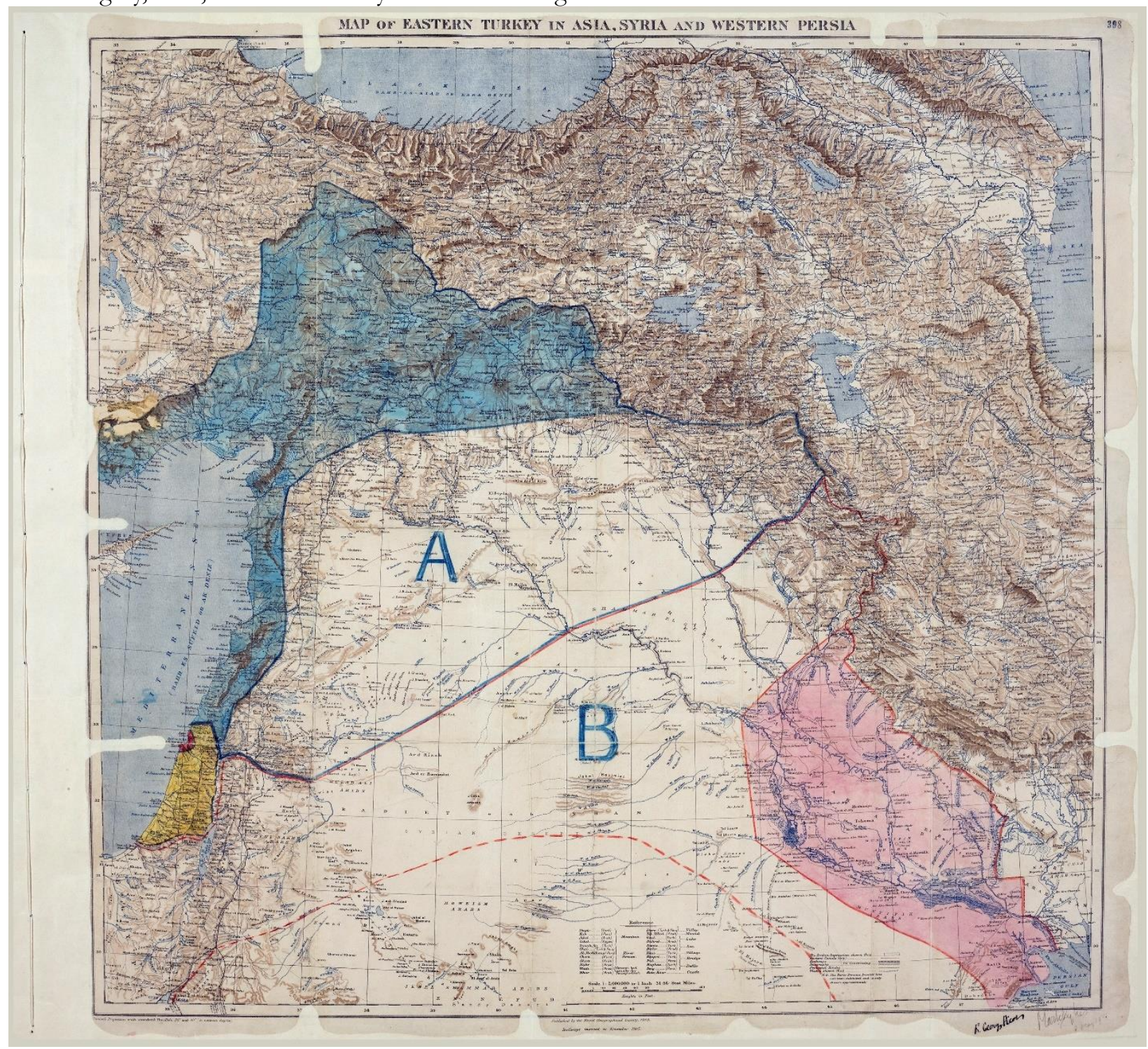

${ }^{6}$ Sykes-Picot agreement art. 11. 
The essays in this Symposium discuss various aspects of Sykes-Picot and its legacies, and the attempt here is to consider both the Treaty's details and in its wider implications for the Middle East and, more broadly, the study of both international law and international relations. Victor Kattan's essay, 'A Twice Promised Land', places Sykes-Picot in the context of a number of assurances that imperial powers, and Britain in particular, had given Arab leaders such as Sherif Hussayn who were intent on establishing their own state. ${ }^{7}$ It is hardly surprising that Sykes-Picot has become a symbol of imperial deception, intrigue, and double-dealing to many Arabs. Further, it is in this way that Sykes-Picot connects with the ongoing controversies about the status of Palestine and Israel. Kattan's essay is a particular case-study of the uses of secret-treaties (a topic Megan Donaldson takes up in detail in her contribution) and the confusion and ambiguities that follow. It traces the continuing political complications it has contributed to and the economic interests that influenced the making of the modern Middle East. Aslı Bâli’s essay squarely addresses the argument made by many scholars and specialists writing on the hundredth anniversary of the treaty, who take Sykes-Picot to represent the artificial boundaries of Middle-Eastern states, and who recommend that the boundaries of these states be redrawn in accordance with ethnic and religious identities and modern geopolitical realities. ${ }^{8}$ This would entail a departure from the international law principle of uti possidetis which suggests that boundaries, even if drawn by colonial powers, must be respected. Once again, the problem of boundaries and ethnic identities resonates beyond the Middle East and into other colonial settings such as Africa, where an active debate continues as to whether the boundaries of African states should be redrawn. Bali makes the important point that Sykes-Picot did not establish the modern boundaries of Middle-Eastern states. Rather they were formulated by the deliberations at Versailles 1919 and afterwards, which were part of a larger enterprise, driven by President Wilson and his concept of the League of Nations and self-determination, that resulted also in the redrawing of the map of Eastern Europe and the creation of the modern state of Poland. It is perhaps ironic that ethnic differences were recognized to exist in Eastern European states, and the League attempted to deal with the resulting problems by providing for a minority treaty system. Bali argues that the campaign to redraw borders may be based on false assumptions, and may indeed simplify Middle-Eastern societies and their histories, overlooking the cosmopolitan traditions which were very much part of their heritage. Karin Loevy's essay, rather than looking to the present for there is surely a tendency to read contemporary concerns into to the intentions of the participants-closely focuses on the regional vision of the treaty, reminding us that nation-states were not the only or even principal concern of the drafters of Sykes-Picot. ${ }^{9}$ Rather, the imperial imaginary saw the Middle East in different geospatial terms, as an area which offered economic and commercial opportunities, awaiting to be developed by the construction of railways and the facilitation of trade. Loevy's reading helps us understand the often neglected economic dimensions of the treaty, something also alluded to by Kattan who points to the discovery of oil in the Mosul. It also suggests another approach to the issue of artificial borders by posing the question of whether it is a regional vision that would be more appropriate for the future of the Middle East.

Sykes-Picot was a scandal, not only to the Arabs who felt deceived and cheated, but to many in Europe and the United States who saw secret treaties and diplomatic intrigue in general as a cause of the Great War. Megan Donaldson's essay explores another and little considered aspect of the treaty, its embodiment of a practice that served a number of important diplomatic functions and that was commonplace amongst imperial powers seeking to preserve a delicate balance of power both within and outside Europe. ${ }^{10}$ Secret treaties and diplomacy

${ }^{7}$ Viktor Kattan, Palestine and the Secret Treaties, 110 AJIL UnBound 109 (2016).

8 Aslı Bâli, Sykes-Picot and "Artificial States", 110 AJIL Unbound 115 (2016).

${ }^{9}$ Karin Loevy, The Sykes-Picot Agreement's Regional Moment: Drawing Lines of Development in a New and Open Space, 110 AJIL UNBOUnD 120 (2016).

${ }^{10}$ Megan Donaldson, Textual Settlements: The Sykes-Picot Agreement and Secret Treaty-Making, 110 AJIL Unbound 127 (2016). 
were condemned by President Wilson, this in the very first of his Fourteen Points. Donaldson explores the different roles played by secret treaties and the attempts made by the League to promote more transparency amongst its members. Article 102 of the United Nations Charter which requires all member states to register, with the Secretariat, copies of any treaty they enter into is one legacy of this campaign. Governments and diplomats convinced of the efficacy of secret diplomacy inevitably developed other techniques to achieve the same purpose despite the campaign for transparency. Finally, Toby Dodge's essay addresses a fundamental paradox: as he points out, Sykes-Picot was never implemented as the imperial capacity that Britain and France assumed proved transient as they both emerged diminished after the war. ${ }^{11}$ Nevertheless, Sykes-Picot, or rather various distorted and simplified versions of it, have had a profound influence on examinations of the Middle East and policy recommendations. Here, Dodge is not focusing so much on Sykes-Picot's impact in the Arab world in general, but on scholars and policy makers. Drawing on Yuen Foong Khong's exploration of the uses of historical analogy to interpret complex events, Dodge suggests how a simplified, mythical version of SykesPicot may operate in a similar way and, as a result, characterize complex societies in simplistic and fixed terms which deny the local populations agency to change their own history. It is this question of agency which may also provide an insight into the enduring significance of the treaty. Sykes-Picot is a striking and vivid example of an imperial mindset, of a belief that empires and the expert officials that ran them can decide the fates of distant lands and peoples. It is redolent of a nineteenth century attitude that animated the drafters of the Berlin Treaty of 1885. It is notable that Sykes-Picot covered much of the territory of modern Iraq; as we survey the destruction of Iraq and consider the optimism and confidence with which the war to liberate and reconstruct that country began, the question must arise as to whether some vestige of the hubris of Sykes-Picot might be found in the thinking of those who attempt, yet again, to remake the modern Middle East.

11 Toby Dodge, The Danger of Analogical Myths: Explaining the Power and Consequences of the Sykes-Picot Delusion, 110 AJIL UNBOUND 132 (2016). 